\title{
Sprouting strategies and dead ends in anti-angiogenic targeting of NETs
}

\author{
Patricia Carrasco, Iratxe Zuazo-Gaztelu and Oriol Casanovas \\ Tumor Angiogenesis Group, ProCURE, Catalan Institute of Oncology - IDIBELL, Barcelona, Spain
}

Correspondence

should be addressed

to O Casanovas

Email

ocasanovas@iconcologia.net

\begin{abstract}
Neuroendocrine tumors (NETs) are a heterogeneous group of neoplasms that arise from cells of the neuroendocrine system. NETs are characterized by being highly vascularized tumors that produce large amounts of proangiogenic factors. Due to their complexity and heterogeneity, progress in the development of successful therapeutic approaches has been limited. For instance, standard chemotherapy-based therapies have proven to be poorly selective for tumor cells and toxic for normal tissues. Considering the urge to develop an efficient therapy to treat NET patients, vascular targeting has been proposed as a new approach to block tumor growth. This review provides an update of the mechanisms regulating different components of vessels and their contribution to tumor progression in order to develop new therapeutic drugs. Following the description of classical anti-angiogenic therapies that target VEGF pathway, new angiogenic targets such as PDGFs, EGFs, FGFs and semaphorins are further explored. Based on recent research in the field, the combination of therapies that target multiple and different components of vessel formation would be the best approach to specifically target NETs and inhibit tumor growth.
\end{abstract}

\section{Key Words \\ - angiogenesis \\ - anti-angiogenic therapy \\ - new anti-angiogenic drugs \\ - neuroendocrine tumors}

\section{Heterogeneity of NETs}

Neuroendocrine tumors (NETs) are defined as a heterogeneous group of neoplasms that arise from cells of the neuroendocrine system. Unfortunately, while many of these tumors are benign, some become malignant. Moreover, even though they are described as rare malignancies, the incidence and prevalence of NETs have increased in the last years, and most of them happen to be in advanced stages at the time of diagnosis (Yao et al. 2008a).

Since NETs show a wide variety of clinical presentations, different terminology and classifications are used to name the different types of neoplasm. In 2010, the World Health Organization (WHO) updated its classification of NETs based on clinical syndrome, differentiation and site of origin (Oberg \& Castellano 2008, Yao et al. 2008a, Klimstra 2016).
NETs can be divided into carcinoids or pancreatic NETs. Based on their clinical syndrome, they are characterized histologically by the presence of specific endocrine tissue markers such as chromagranin A, synaptophysin and neuro-specific enolase, or by their ability or inability to produce bioactive peptides and neuroamines, such as serotonin, histamine, prostaglandins, substance $\mathrm{P}$, insulin, gastrin, glucagon and vasoactive intestinal polypeptide (Massironi et al. 2008). Related to their pathological grade and state of differentiation and aggressiveness, NETs are divided into three different groups: low grade (G1), intermediate grade (G2) and high-grade tumors (G3). Finally, NETs can be also grouped according to the localization of the tumor and their embryonic origin in the foregut (lungs,

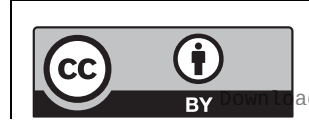

This work is licensed under a Creative Commons Attribution 3.0 Unported License. 
thymus, stomach and duodenum), the midgut (jejunum, ileum, appendix and proximal large bowel) and the hindgut (distal colon and rectum).

As depicted by the complexity of NET classification, the heterogeneity of NETs has further contributed to their limited therapeutic options. Hence, there is an urge to develop an efficient therapy to treat NET patients.

\section{Insight into angiogenic hallmarks}

NETs are characterized for being highly vascularized tumors with the ability to produce large amounts of proangiogenic molecules. This is a feature of normal endocrine glands, which have a dense vascular network that facilitates hormone secretion and dumping to the bloodstream. In detail, some studies have shown that intratumoral vessel density is usually 10 -fold higher in NETs than in carcinomas. Another trait of NET-composing cells is their capacity to synthesize and secrete high levels of the vascular endothelial growth factor (VEGF) (Capdevila et al. 2014). VEGF is the main mediator of tumor angiogenesis due to its effects as endothelial cell mitogen and vascular permeability-inducing agent.

Given that growing tumors require high amounts of oxygen and nutrients to allow the proliferation of tumors cells, tumor angiogenesis (the process by which blood vessels penetrate and grow inside the tumor) becomes critical for the survival of solid neoplasms, tumor invasion and metastatic dissemination. Additionally, there is a paracrine release of anti-apoptotic factors from activated endothelial cells of the newly formed vasculature that also contributes to tumor growth. Consequently, tumor cells tend to promote an event called angiogenic switch that occurs when the concentration of proangiogenic factors exceeds that of anti-angiogenic molecules (Hanahan \& Folkman 1996). Therefore, when the shift in the balance of angiogenic inducers and inhibitors toward a proangiogenic outcome occurs, neovascularization inside the tumor is engaged.

However, the newly formed tumor blood vessels are structurally and functionally aberrant, presenting all the vascular components affected. In fact, tumor vessels show tortuosity, leakiness and lack of pericyte coverage, which leads to intratumoral hypoxia (Baluk et al. 2005, Jain 2005). Moreover, the endothelial cells composing the tumor vasculature are also abnormal, losing their polarity and allowing their detachment from the basement membrane which ends with their stacking upon each other and results in aberrant thickness of the blood vessels walls (Baluk et al. 2005). Tumor endothelial cells also produce extensions into the lumen and form sprouts, with leading tip cells penetrating deep into tissue, thereby helping the invasion process. Additionally, these endothelial cells contain multiple fenestrations and other trans-endothelial channels, resulting in hemorrhage and increased interstitial fluid pressure.

Experimental data show that VEGF plays an important role in endocrine tumorigenesis and tumor progression. This has been well studied in a multistage pancreatic endocrine tumorigenesis model, the RIP1-Tag2 transgenic mouse, in which the angiogenic switch occurs in premalignant lesions and the neoangiogenic process persists during tumor progression. In the RIP1-Tag2 model, the transgenic mouse SV40 T-antigen (Tag) is expressed in endocrine beta cells under the control of the insulin promoter. The transgene converts normal insulin-producing beta cells of the pancreatic islets into islet cell carcinomas. Therefore, normal islets express the Tag oncogene, and RIP1-Tag2 mice are morphologically asymptomatic until 3-4 weeks of age. Hyperplasic islets start to arise stochastically (increasing to $50 \%$ of the islets by 10 weeks of age), showing beta-cell hyperproliferation, dysplasia characteristics and carcinoma in situ. In addition, switching of islet capillaries also forms angiogenic islets from these hyperplasic islets. This switch is characterized by endothelial proliferation, vascular dilation and microhemorrhaging. Tumor progression occurs by $12-13$ weeks when the small encapsulated tumors (adenomas) progress into large adenomas and invasive carcinomas (Hanahan 1985). Tumor transition from endocrine hyperplasia to neoplasia is related to the acquisition of angiogenic properties (Hanahan \& Folkman 1996), which can be blocked by the use of several antiangiogenic agents (Bergers \& Benjamin 2003). The RIP1Tag2 model has been widely used to study the sensitivity of NETs to different anti-angiogenic drugs (Hanahan 1985). In fact, several anti-angiogenic treatments have been evaluated to prevent the angiogenic switch in premalignant lesions and restrict the rapid expansion of tumors.

Different therapeutic options exist for NETs patients depending on the localization of the primary tumors, the patterns of metastatic spread and the hormonal activity. The current standard procedure for localized disease is surgical resection, which still is the only curative strategy for some NETs. At the same time, treatments for patients with metastatic disease include control of tumor growth and alleviation of hormone-mediated symptoms (Kunz 2015). 
However, conventional drugs are not selective for tumor cells and produce toxicity in normal tissues. Due to the limitations, vascular inhibitory targeting was proposed as a new approach to fight against tumor growth. Although the rationale of using angiogenesis inhibitors as anticancer drugs was received with skepticism among researchers when first presented by Dr Folkman in the 70s, (Folkman 1971), it soon startled an active research in the field, with the identification of several angiogenic inhibitors and subsequent clinical trials. This promising strategy leads to tumor cell death by the lack of oxygen and nutrient deprivation as a consequence of blood vessels. In this context, growth factors, their receptors and subsequent signaling cascades involved in vascular homeostasis are promising targets in angiogenesis inhibition.

\section{Exploiting the current therapeutic repertoire}

There are several factors such as tumor location, hormone secretion, invasiveness and metastasis that help to define the appropriate antitumor treatment. Since tumor survival requires blood supply, different strategies can be used to reduce tumor vasculature. The vascular network can be inhibited at different levels, such as targeting endothelial cell proliferation, pericytes or extracellular matrix remodeling factors (Fig. 1). NETs exhibit overexpression of several growth factors and their receptors, such as VEGF, VEGFR and PDGFR (Terris et al. 1998, Fjallskog et al. 2003). Therefore, growth factors, their receptors and subsequent signaling cascades are promising targets in angiogenesis inhibition. In fact, many drugs have been developed to block growth factors and tyrosine kinase (TK) receptors.

Antivascular therapies have some advantages compared with conventional drugs. Chemotherapeutic drugs are not selective for tumor cells and produce toxicity in normal tissues with high proliferative rates such as the bone marrow, the gastrointestinal tract or the hair follicles. By contrast, anti-angiogenic therapies trigger cell death of tumors cells supplied by vessels. In the last years, numerous approaches have been made to evaluate the effects of anti-angiogenic agents and to understand their mechanism of action, most of which are still unknown.

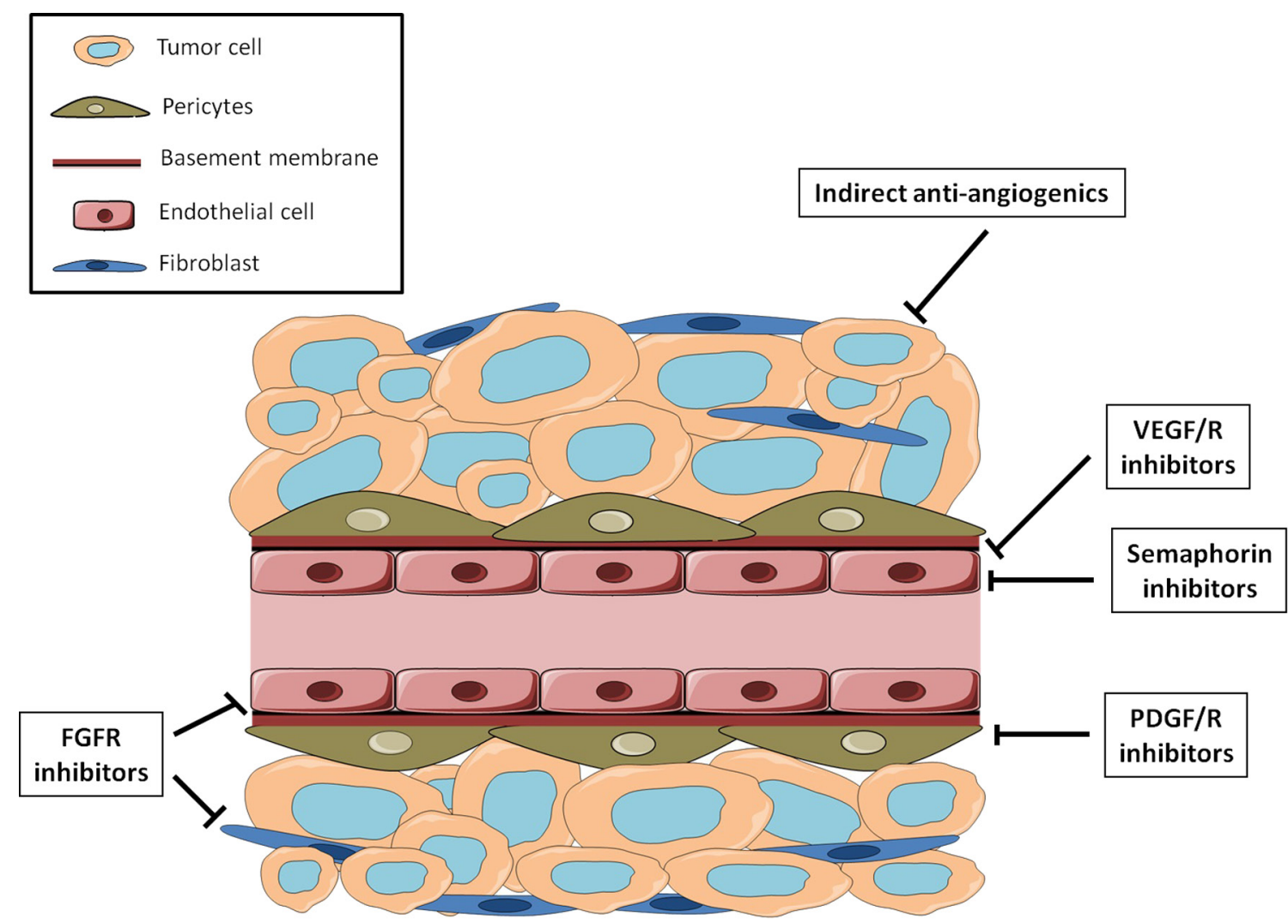

Figure 1

Current and novel targets of anti-angiogenic strategies in tumor vessels. While semaphorin and VEGF/R inhibitors are described to act upon endothelial cells exclusively, FGFR inhibitors can act both on endothelial cells and tumor stroma. PDGF/R is a specific inhibitor of pericytes, while indirect anti-angiogenics (i.e. MTOR inhibitors) are specific inhibitors of non-vascular cells.

http://jme.endocrinology-journals.org DOI: 10.1530/JME-17-0029 (c) 2017 The authors Printed in Great Britain
Published by Bioscientifica Ltd 
Importantly, many drugs have been developed and tested in well-differentiated NETs to block angiogenic growth factors and their receptors. Some of them, such as bevacizumab and sunitinib, have been already approved by the US Food and Drug Administration (FDA) for the treatment of some of these tumor types.

\section{Current classical anti-angiogenic therapies: VEGF/R targeted therapies}

Tumor cells can deregulate TK activity, thereby affecting many aspects of cellular function and conferring advantages to cancer cells, such as decreased apoptosis, increased proliferation, invasiveness and angiogenesis. TK inhibitors (TKIs) were postulated as a good approach for anticancer therapy due to the presence of a dual effect: they block both tumor cell proliferation and proangiogenic signaling pathways.

TKIs are small molecules with the ability to interact physically with the highly conserved kinase domains shared by different VEGFRs, as well as PDGF receptors, FGF receptors (FGFRs), EGF receptors (EGFR), Raf kinases and c-kit (a receptor of the pluripotent cell growth factor or stem cell factor), hence blocking the receptor activation (Gotink \& Verheul 2010). TKIs can also be antibodies that bind to growth factors and prevent their binding to their receptors and their subsequent activation.

TK receptors are transmembrane proteins with an extracellular binding domain for ligands and an intracellular kinase domain. When the ligand binds the receptor, it is activated and stimulates an intracellular signaling cascade. The interaction between the inhibitor and the receptor directly inhibits tyrosine phosphorylation and the subsequent downstream proangiogenic signaling networks (Baka et al. 2006, Ivy et al. 2009).

Several TKIs have been developed for the treatment of many cancers. However, the efficacy of each inhibitor depends on the expression levels of the different growth factors or TK receptors they are blocking, and therefore different types of tumors may respond differently to each drug. The most important anti-VEGFR and anti-PDGF inhibitors are sorafenib, sunitinib and pazopanib (Gotink $\&$ Verheul 2010).

VEGF-targeted therapy Angiogenesis in PNETs and carcinoids is regulated by the influence of VEGF pathway (Kulke 2008, Raymond et al. 2011b). VEGF family is formed by six different members: VEGF-A, -B, -C, -D, -E and placental growth factor (PIGF), with different roles in angiogenesis. VEGF can be produced by endothelial cells and promotes vascular homeostasis and development, or by tumor or stromal cells in a paracrine fashion, increasing vessel branching and tumor vessel abnormalities. VEGF levels are regulated by hypoxia, oncogene activation, downregulation of tumor suppressors, cytokines and growth factors levels. There are three different VEGFRs: -1, $-2,-3$, all of them expressed in endothelial cells. VEGFR1 was first identified and, although its function is still unknown, it may act as a decoy receptor, reducing the number of unbound, circulating VEGF available to bind VEGFR2. VEGFR1 might also have a role in endothelial cell recruitment and mitogenic signal induction. VEGFR2 is the low affinity receptor for VEGF, and it is known to be involved in angiogenesis and hematopoietis stimulation. The interaction between VEGF and VEGFR2 results in receptor dimerization, TK phosphorylation and activation of the signaling pathway involved in endothelial cell proliferation, migration and survival. It also contributes to the upregulation of molecules involved in extracellular matrix degradation.

VEGF pathway can be blocked by different strategies: inhibiting the VEGF ligand (e.g. bevacizumab), inhibiting the VEGFR (e.g. ramucirumab), soluble VEGFR/VEGFR hybrids (e.g. VEGF-Trap) and TKIs with selectivity for VEGFRs (e.g. sunitinib and sorafenib) (Fig. 1). The most important anti-VEGF drug is bevacizumab (Avastin; Genentech). Bevacizumab is a recombinant humanized monoclonal antibody against all isoforms of VEGF. It has been approved by the US Food and Drug Administration (FDA) for the treatment of several types of NET tumors but only in combination with other endocrine targeted therapies, such as octreotide (Yao et al. 2008b) or 2-methoxyestradiol (Kulke et al. 2010). For instance, a phase III clinical trial has been developed to test the effectivity of octreotide, a somatostatin analog, together with bevacizumab or INF $\alpha-2 b$ in patients with metastasis or unresectable NETs (NCT00569127). In conclusion, the combination of bevacizumab and octreotide was associated with longer time to treatment failure (TTF) and more frequent radiologic response. Nevertheless, no significant differences in progression-free survival (PFS) were observed, suggesting that both bevacizumab and INF $\alpha-2 b$ bare similar antitumor activity in patients with advanced NETs.

TK receptors, apart from being expressed in endothelial cells, are expressed in tumor and stromal cells. In addition, TKIs often target more than one type of receptors, so the inhibition of TK can affect various types of cells http://jme.endocrinology-journals.org DOI: 10.1530/JME-17-0029
(C) 2017 The authors Printed in Great Britain
Published by Bioscientifica Ltd 
(Krause \& Van Etten 2005). Therefore, multitargeted TKIs, such as sorafenib and sunitinib, have demonstrated efficacy against various solid tumors in different clinical trials.

Sorafenib (Nexavar; Onyx Pharmaceuticals) is an oral synthetic compound with multiple targets, which inhibits angiogenesis and cell growth signaling. It has a dual effect since it can inhibit a component of the RAF/MEK/ERK signaling pathway, Raf-1, which controls proliferation and cell division. On the other hand, it can also inhibit VEGFR2-3 and PDGFR $\beta$ signaling pathway, thus inhibiting angiogenesis (Llovet et al. 2008, Ivy et al. 2009, Raymond et al. 2011b). In a phase II clinical trial, sorafenib demonstrated a partial response of $10 \%$ in patients with progressive metastatic NETs (NCT00131911).

Another component is Sunitinib (Sutent; Pfizer), which is an orally administered small molecule that inhibits multiple targets such as VEGFR1-3, plateletderived growth factor receptor $\alpha$ and $\beta$ (PDGFR $\alpha-\beta$ ), colony-stimulating factor-1 receptor (CSF-1R) and c-kit, thereby blocking angiogenesis and cell proliferation. It has been approved by the US Food and Drug Administration (FDA) and it has been tested in most of NETs in a phase III trial which resulted in an increase in patient progressionfree survival (Raymond et al. 2011a, Delbaldo et al. 2012).

In the same line acts Pazopanib (Votrient). Pazopanib is an oral small molecule and multitargeted TKI that inhibits tumor angiogenesis by blocking VEGFR1, -2 and -3 , PDGFR and stem cell factor receptor (c-Kit). Pazopanib produces dual effects on both tumor and endothelial cells, acting as an anti-angiogenic and anti-tumoral agent (Kumar et al. 2007, Hamberg et al. 2010, Ahn et al. 2013). Among others, a phase II clinical trial was recently carried out to assess the activity of pazopanib after failure of other systemic treatments in advanced NETs (NCT01280201). Pazopanib demonstrated clinical activity in patients with advanced NETs independently from previous treatments. Moreover, CTCs, soluble VEGFR-2 and VEGFR-3 gene polymorphisms were found to be potential biomarkers for selecting patients for pazopanib treatment (Grande et al. 2015). Another anti-VEGF drug is Vatalanib (Novartis), a TKI of all three VEGFR1-3 and several non-VEGF receptors, such as platelet-derived growth factor receptor (PDGFR).

The capacity to inhibit depends on the molecule and it is also proportional to the number of downstream affected targets. For example, Bevacizumab affects all the receptors influenced by VEGF, while sunitinib, pazopanib or vatalanib target the three VEGF receptors, as well as PDGF receptors and other non-VEGF receptors. This means that Bevacizumab has a modest inhibitory effect, contrary to the multitargeted inhibitors like sunitinib, whose inhibitory capacity is profound across all cell, tissue and tumor types. These results led the investigators to conclude that blocking the classical VEGF pathway alone does not consistently alter neovascularization in tumors. Not only that, but more consistent results are obtained when multiple growth factor pathways are simultaneously affected.

\section{Emerging targets in angiogenic therapy}

Additionally to VEGF, several other growth factors and receptors are involved in tumor angiogenesis signaling processes of NETs including platelet-derived growth factor (PDGF), platelet-derived growth factor receptors alpha and beta (PDGFR alpha and beta), basic fibroblast growth factor (FGF), basic fibroblast growth factor receptor (FGFR), transforming growth factor alpha and beta, epidermal growth factor (EGF), epidermal growth factor receptor (EGFR), guidance molecules (semaphorins), etc.

There is a need to explore different mechanisms regulating different components of vessels to understand their contribution to tumor progression and treatment response. Many of these pathways can be also inhibited by small molecules or by combination of different agents that target multiple proangiogenic pathways such as VEGF together with PDGF, FGF or EGF (Fig. 1).

PDGF-targeted therapies The PDGF family is composed of four polypeptide chains that assemble into five dimeric isoforms (PDGF-AA, PDGF-BB, PDGF-AB, PDGF-CC and PDGF-DD) that bind to two TK receptors (PDGFR $\alpha$ and PDGFR $\beta$ ) (Andrae et al. 2008). These molecules are implicated in pericyte coverage and can also regulate tumor vessel normalization. In fact, they have shown to have critical roles in cellular processes such as proliferation, survival and motility during tumor growth and invasion (Heldin \& Westermark 1999). The proangiogenic PDGF and its receptor PDGFR work together in a paracrine manner: sprouting endothelial cells release PDGFB to chemoattract pericytes that express its receptor (Hellberg et al. 2010). Hence, PDGFR $\beta$ acts as an attractant, stimulating cell migration, proliferation and cell fate. Consequently, the inhibition of PDGF signaling causes pericyte deficiency, leading to vessel leakage, tortuosity, microaneurysm formation and bleeding. Moreover, deficiencies in PDGFB or in pericytes form abnormal vessels.

Preclinical studies in patients have demonstrated that deficiencies in pericyte coverage disassemble the vessel wall and promote tumor invasion and metastasis

Published by Bioscientifica Ltd 
(Yonenaga et al. 2005). In addition, overexpression of PDGFD normalizes tumor vessels and increases drug delivery; while the inhibition of PDFGRB also improves drug delivery and the effectivity of chemotherapy (Hellberg et al. 2010). By monitoring tumorigenesis in the RIP1-Tag2-PDGFD knockout mouse model of pancreatic neuroendocrine tumors, it was shown that disruption of PDGF-DD signaling significantly delayed tumor growth. Therefore, aberrant platelet-derived growth factor receptor beta (PDGFR $\beta$ ) signaling in cancer has motivated the development of several antagonists currently used in the clinical setting such as imatinib (Novartis) (Fig. 1). Imatinib is an oral small molecule that affects the inhibition of ABL, c-kit and PDGFR signaling pathways. Due to its inhibitory potency, imatinib has significantly improved the treatment of cancers that crucially depend on the activation of these growth factor receptors. However, it has a low response ratio when compared to other anti-angiogenic agents, since it elicits its effects on PDGFR and lacks VEGFR inhibitory activity.

FGF-targeted therapies A second proangiogenic pathway involves the fibroblast growth factor (FGF) superfamily, formed by 23 different ligands and four TK receptors (FGFR-1-4). The binding of an FGF to an FGFR induces receptor dimerization followed by receptor autophosphorylation and activation of downstream signaling pathways, activating the phosphorylation of several tyrosine residues in the $\mathrm{COOH}$ terminal tail, kinase domains and juxtamembrane region. This family elicits a dual action. On the one hand, it is involved in endothelial cell migration, proliferation and differentiation into a functional capillary vessel (Presta et al. 2005). For example, FGF1 and 2 directly promote endothelial cell proliferation, migration, vessel formation and maturation (Lieu et al. 2011). On the other hand, it also has an indirect effect concerning the regulation of the production of other proangiogenic molecules like VEGF, angiopoietin-2 (Ang-2) or interleukin-8 (IL-8) by tumor or stromal cells (Beenken \& Mohammadi 2009). In addition to angiogenesis stimulation, FGF also regulates stromal fibroblasts and, consequently, produces an effect in tumor angiogenesis, since it is also an inducer of tumor cell proliferation via FGFR activation.

Blockade of FGF/FGFR signaling as a therapeutic approach to cancer is accomplished by either monoclonal antibodies that inhibit FGF binding by using small molecules that inhibit FGFR TK activity, or by allosteric modulators that adhere to the extracellular region of
FGFR domain (Fig. 1). There are some selective antiFGFRs such as AZD4547 (AstraZeneca). AZD4547 is a highly active pan-FGFR selective inhibitor that suppresses FGFGR signaling. Other selective inhibitors include BGJ398 (Novartis) that inhibits FGFR1-3, and LY287445, a selective pan-FGFR inhibitor. Anti-FGFR inhibitors are often weak, and for this reason, the combination of FGF inhibition with other drugs becomes necessary. In this context, since FGF signaling cooperates with VEGF pathway in tumor angiogenesis, the investigation of brivanib was prompted. Brivanib is a dual and selective FGF/VEGF inhibitor that was studied in the RIP1-Tag2 mouse model as a monotherapy. It showed blocking efficacy in the majority of samples analyzed and produced no signs of revascularization (Allen et al. 2011).

Other inhibitors that have been reported include Dovitinib, a potent TKI that also shows a potential antiangiogenic action through the inhibition of FGFR, VEGFR and PDGFR; E3810, another potent dual inhibitor of VEGFRs and FGFRs; and Nintedanib, an oral compound with the capacity of blocking VEGFR, PDGFR and FGFR, showing highest activity against VEGFR1, 2, 3 and FGFR2.

It is evident that stromal cells play a key role in tumor angiogenesis and, consequently, in tumor progression, due to its function in matrix remodeling, tumor invasion and metastasis (Picard et al. 1986, Grey et al. 1989, Camps et al. 1990). Accordingly, the inhibition of these pathways could be an alternative to the classical antiVEGF therapies.

EGF-targeted therapies Another proangiogenic pathway includes the epidermal growth factor (EGF)-like family of growth factors and their TK receptors (EGFRs): EGFR (ErbB1, HER1), ErbB2 (HER2, neu in rodents), ErbB3 (HER3) and ErbB4 (HER4). Upon ligand binding, receptor dimerization occurs, and the autophosphorylation of specific tyrosine residues takes place. These residues will then serve as binding sites for adaptor molecules and signal transducers. EGF family is involved in cell proliferation, differentiation, migration, adhesion, survival, inhibition of apoptosis and angiogenesis (Ritter \& Arteaga 2003). EGF signaling pathway activation produces the release of proangiogenic factors such as VEGF, IL-8 and EGF from tumor and stromal cells. Therefore, EGF has a dual role: since they are expressed by tumor cells and endothelial cells, inhibitors of EGFR-activity can synergistically act as antitumor drugs too.

Some studies have shown that EGF expression is upregulated in NETs, where it is associated with http://jme.endocrinology-journals.org DOI: 10.1530/JME-17-0029
(C) 2017 The authors Printed in Great Britain
Published by Bioscientifica Ltd 
tumor proliferation and, therefore, correlates with poor prognosis (Shah et al. 2006). Consequently, anti-EGFRbased therapies have fantastic potential as anti-tumoral drugs. In addition to its effects on tumor cells, EGF is also expressed in vessels and its expression produces an increase in endothelial cell proliferation and survival. Moreover, it has been described that EGFR is expressed in tumor vessels of some types of cancer (Kedar et al. 2002, Holsinger et al. 2003, Sini et al. 2005, Thaker et al. 2005, Yokoi et al. 2005, Amin et al. 2006). Taken altogether, all these data suggest that apart from tumor cells, endothelial cells could be also target for anticancer therapy by EGFRtargeting drugs.

Some anti-ErbB therapies show inhibition of tumor angiogenesis in preclinical studies (Folkman 2007). For example, the administration of an EGFR inhibitor produces a decrease in EGFR on tumor vessels, which consequently generates a decrease in tumor angiogenesis due to an increase in endothelial cells apoptosis in some xenograft tumor models (Sini et al. 2005). Therefore, several strategies to inhibit EGFR have been developed and subsequent clinical studies have proven promising. There is a humanized anti-EGFR monoclonal antibody, cetuximab (IMC-C225), which targets the extracellular domain of the receptor, producing a downregulation of proangiogenic mediators accompanied by a reduction in vessel density and metastases (Ellis 2004, Huether et al. 2005). It has been reported that cetuximab suppresses neovascularization in some types of cancer such as epidermoid, lung, bladder, head and neck, and colon tumor xenografts (Petit et al. 1997, Perrotte et al. 1999, Huang et al. 2004, Morelli et al. 2006).

Another specific and reversible EGFR-TK inhibitor is Gefitinib (ZD1839), a synthetic anilinoquinazoline with a low molecular weight (Ranson \& Wardell 2004). It blocks receptor autophosphorylation, induces cell cycle arrest and reduces cell proliferation in tumor cells that express EGFR. Some studies in neuroendocrine cell lines show a role for EGFR as a possible target and report efficacy of some EGFR inhibitors in NETs. Höpfner's group demonstrated in vitro that gefitinib produced a potent inhibition of the growth of NE gastrointestinal tumor cells by inducing cell cycle arrest and/or apoptosis, showing a promising role in inhibiting tumor growth (Hopfner et al. 2003). In addition to its direct effect on tumor cells, gefitinib has also an anti-angiogenic role through the inhibition of PI3K/Akt pathway, and it has been reported that it completely blocks neovascularization in some types of cancer (Iivanainen et al. 2009). This study also reveals that gefitinib regulates tumor angiogenesis by two mechanisms: by reducing pericyte coverage of vessels, producing the instability of these new vessels; and by reducing the recruitment of BM-derived progenitor cells to the perivascular space of tumor vessels. In consequence, gefitinib could elicit its effect directly, blocking EGF and neovasculatization, or indirectly, by inhibiting VEGF or interleukin-8 production.

Another molecule with similar properties to gefitinib is Erlotinib (Tarceva; Genentech, OSI Pharmaceutical, Roche). Erlonitib is an oral, potent and selective inhibitor of the EGFR (Moyer et al. 1997). This small molecule inhibits EGFR in a reversible manner, preventing the autophosphorylation of the receptor and, consequently, blocking its activity.

On the whole, these data suggest that tumors that express EGFR in both tumor and endothelial cells respond better to anti-EGFR therapy than those where only the tumor cells express the receptor (Baker et al. 2006). However, as monotherapy, some studies reveal that EGFR inhibitors have modest activity in solid tumors. The combination of EGF inhibitors either with conventional cytostatics or with other targeted agents could be the smartest strategy to block completely tumor angiogenesis (Klagsbrun et al. 2002, Huether et al. 2005, Moore 2005, Bourhis et al. 2006).

Semaphorin-targeted therapies Semaphorins are a large family of membrane-bound and secreted glycoproteins involved in guidance signaling pathways, in both attractive and repulsive activities, during the vascular and nervous system formation (Kolodkin et al. 1993, Luo et al. 1993). Moreover, they also have a role in cell adhesion and motility, angiogenesis, immune response and are key components of tumor progression (Tamagnone \& Comoglio 2004, Zhou et al. 2008). Ligands within the semaphorin family are formed by a highly conserved extracellular domain, essential for semaphorin function, that mediates the binding to multimeric receptor complexes, mainly formed by plexins and neuropilins (NRPs) (Suchting et al. 2005). Semaphorins have been grouped into eight classes: classes 1 and 3 include invertebrate orthologues, whereas classes 3-7 are composed of vertebrate family genes, and class 5 is formed by viral semaphorins. Their receptors, plexins and neuropilins, are expressed in a variety of cell types such as endothelial cells, bone marrow-derived cells and cancer cells. In vertebrates, plexins are grouped in nine types of receptors, which are further divided into four subfamilies on the basis of overall similarity: plexin A (1-4), plexin B (1-3), plexin C1 and plexin D1. The extracellular

Published by Bioscientifica Ltd. 
domain of plexins contains three PSI domains, whereas their cytoplasmic domain is highly conserved. Neuropilin receptors, grouped in NP1 and 2, are formed by a singlespan transmembrane glycoprotein. They are associated with several intracellular signaling pathways involved in integrin function regulation, cytoskeletal dynamics, cell adhesion and migration.

As for tumor progression, semaphorins can act directly influencing the behavior of cancer cells, or indirectly, by modulating angiogenesis. Moreover, depending on their post-translational modifications, they can have a dual role in activating or inhibiting tumor progression and angiogenic response. For example, SEMA3A, 3B, 3E and $3 \mathrm{~F}$ act as negative regulators of tumor angiogenesis (Klagsbrun et al. 2002, Schwarz et al. 2004), while SEMA $3 \mathrm{CD}$ and $5 \mathrm{~A}$ promote tumor angiogenesis (Basile et al. 2004, Banu et al. 2006, Sadanandam et al. 2010b, Miyato et al. 2012).

Semaphorins as suppressors of tumor angiogenesis In developing vessels, the expression of Sema3A by endothelial cells produces the inhibition of angiogenesis, impairing endothelial cell migration and inducing cell apoptosis (Bates et al. 2003, Serini et al. 2003, Guttmann-Raviv et al. 2007). It has been described that Sema3A has a key role as an anti-angiogenic molecule; however, it has been shown that its expression is lost during tumor progression. In consequence, the overexpression of Sema3A could help to inhibit tumor growth and normalize the tumor vasculature. Some studies have shown that overexpression of Sema3A in different mouse models of cancer correlates with decreased tumor invasion (Herman \& Meadows 2007, Casazza et al. 2011). More concretely, it has been shown that the re-expression of Sema3A in RIP-Tag2 tumors by adeno-associated virus improves tumor vascular function, reducing vascular density and increasing pericyte coverage, and prolongs the survival of treated animals (Maione et al. 2009, 2012). Thus, Sema3A re-expression normalized tumor vasculature, reducing the number of immature tumor blood vessels and re-established the normoxia in tumor tissue, thereby inhibiting tumor progression. Other studies show similar results in melanoma cells and in prostate cancer cells. In detail, it is described that the overexpression of Sema3A in these tumor types also suppresses tumor growth and tumor progression (Herman \& Meadows 2007).

These data propose the overexpression of Sema3A as an attractive alternative approach for anticancer therapy in NETs. However, after some treatment cycles, emerging resistance to these therapies has been described. In this context, the combination of Sema3A with other TKIs such as sunitinib could be an interesting strategy (Maione et al. 2012).

Another important Sema3 molecule with a potent anti-angiogenic activity is Sema3F. It has been shown to suppress tumor angiogenesis and metastasis in several cancer mouse models (Kessler et al. 2004). Similarly to Sema3A, Sema3F acts as a vascular normalizing agent, blocking peritumoral vessel sprouting, tumor cell adhesion and migration. Moreover, it has also been described as a metastasis suppressor in different animal models (Bielenberg et al. 2006).

Sema3E is also involved in the regulation of tumor angiogenesis and cancer progression. In fact, its re-expression in a xenograft melanoma model strongly reduces metastasis formation (Roodink et al. 2008). Finally, Sema3B in addition to its direct antitumor effect can also acts as an angiogenic inhibitor (Varshavsky et al. 2008).

These findings further corroborate that the aberrant vasculature in tumors is a direct consequence of an imbalance between the pro- and anti-angiogenic factors. Therefore, the restoration of this equilibrium in tumors by re-expression of Sema3A, E and F, is crucial for tumor vasculature normalization and, consequently, tumor growth control.

Semaphorins engaging tumor angiogenesis Apart from their beneficial role as tumor angiogenesis inhibitors, it has been shown that some semaphorins also contribute to trigger tumorigenesis and metastasis (Basile et al. 2004, 2006, Wang et al. 2015).

The most studied proangiogenic Sema is Sema4D, which promotes tumor angiogenesis by inducing endothelial cell proliferation, adhesion and migration, as well as Sema3C, whose expression in some types of cancer has been correlated with tumor progression (Galani et al. 2002, Banu et al. 2006, Herman \& Meadows 2007). Sema3C promotes tumor migration and is highly expressed in metastatic tumor cells. Semaphorin 3C also promotes endothelial cell proliferation, migration and tube formation.

Sema4D exerts its proangiogenic activity through binding to its PlexinB1 receptor in endothelial cells (Basile et al. 2004). Regarding the signaling mechanisms, two alternative pathways have been proposed. While one involves RhoA activation, engagement of integrins and activation of TKs (Basile et al. 2005, 2007a), the other http://jme.endocrinology-journals.org DOI: 10.1530/JME-17-0029
() 2017 The authors Printed in Great Britain
Published by Bioscientifica Ltd 
proposes Met activation upon Sema4D-PlexinB1 as the triggerer of TK phosphorylation cascade (Conrotto et al. 2005). In both cases, Sema4D-mediated activation leads to cytoskeletal reorganization in endothelial cells and an increase in their migratory properties.

Considering its role in angiogenesis, the potential association of Sema4D with tumor angiogenesis was studied and it was found to be highly expressed in different type of tumors such as breast, head, neck and oral (Basile et al. 2006, Ch'ng et al. 2007). Moreover, several clinical studies have showed that a higher Sema4D expression is correlated with higher necrosis ratio, mitotic ratios and poorer prognosis (Ch'ng \& Kumanogoh 2010).

At the molecular level, induction of angiogenesis starts with the cleavage of the extracellular portion of Sema4D by matrix metalloproteinase type 1 (MT1-MMP, also known as MMP14) and binds to PlexinB1 or to other lower affinity receptors such as PlexinB2, allowing it to act on local and distant tumor niches (Basile et al. 2007b, Fazzari et al. 2007) On the other hand, Sema4D can regulate tumor-associated macrophages (TAMs) and other monocytic cells of the tumor stroma. In this context, Sema4D showed an inhibitory effect on cell migration (Delaire et al. 2001). These results could be interpreted as a mechanism of tumor cells for the retention of immune cells in the tumor stroma, further potentiating inflammation and cytokine production.

Regarding the way forward to the clinic for semaphorin targeting, an antibody against anti-Sema4D, MAb67, has been developed (Vaccinex Inc, Rochester, NY, USA). In preclinical studies, anti-Sema4D/MAb67 has shown to inhibit tumor growth by promoting immune infiltration and reducing immunosupression (Evans et al. 2015). These results, together with $\mathrm{PK} / \mathrm{KD}$, safety and immunolocalization studies in rat and cynomolgus monkeys, supported the initiation of a phase I clinical study to assess the safety and tolerability of VX15/2503 (an MAb67-derived humanized antibody) in patients with advanced solid tumors (NCT01313065). Another proangiogenic molecule is Sema5A, a transmembrane semaphorin which binds to PlexinB3, increasing angiogenesis, tumor growth, invasion and metastasis (Pan et al. 2010, Sadanandam et al. 2010b), and is a putative metastatic marker for pancreatic cancer (Sadanandam et al. 2007). It has been demonstrated that Sema5A, as a proangiogenic molecule, can regulate several processes during angiogenesis, such as endothelial cell proliferation, survival and migration and sprouting of blood vessels (Sadanandam et al. 2010a). In fact, it has been shown that secreted Sema5A enhances invasiveness and metastasis of tumor cells via ERK phosphorylation, while proliferation of endothelial cells is promoted through upregulation of angiogenic factors (Sadanandam et al. 2012).

To sum up, Semaphorin family members are essential regulators of the tumor microenvironment, since their expression is often altered in tumor samples compared to normal tissues. Importantly, the expression of certain inhibitory semaphorins is decreased in some aggressive tumor cells, supporting the idea that they work as tumor suppressing genes. In contrast, proangiogenic and tumorigenic semaphorins are upregulated during malignant processes, which may indicate that their inhibition could be a potential therapeutic approach (Fig. 1). On account of the data resumed above, currently, semaphorins are highlighted as alternative anti-angiogenic targets that if adequately inhibited or activated could have the potential to impair tumor growth (Pircher et al. 2014).

\section{Targeted therapies with indirect anti-angiogenic} effects There are some molecules that, although apparently not directly involved in any angiogenic pathway, may exert their antitumor activity through indirect anti-angiogenic effects. This is the case of mTOR inhibitors and somatostatin analogs (Fig. 1). mTOR is an intracellular serine-threonine kinase that regulates cell signaling processes controlling apoptosis, proliferation, cell growth and metabolism. In addition to their multiple roles, mTOR inhibitors also demonstrate anti-angiogenic properties. Upon the activation of the signaling pathway, PI3K triggers the generation of phosphatidylinositol 3,4,5-triphosphate (PIP3), which provokes the subsequent activation of AKT, a serine/threonine kinase that activates multiple cellular target proteins. It has been shown that mTOR activation may participate in pancreatic NET progression (Missiaglia et al. 2009). Therefore, the inhibition of mTOR pathway is a promising strategy for drug therapy.

The natural antibiotic rapamycin (sirolimus) is one of such inhibitors of mTOR and acts as a tumor suppressor. There are two analogs of rapamycin: temsirolimus (Wyeth Pharmaceuticals), a soluble ester analog involved in cell cycle inhibition whose use was abandoned after the first trials (Duran et al. 2006, O'Donnell \& Ratain 2007); and everolimus (Novartis), with a high oral bioavailability and potential anti-angiogenic properties. Everolimus has been tested successfully for its anti-neoplasic potency, and it has been approved for its use in patients with advanced pancreatic NETs, since it significantly improved

Published by Bioscientifica Ltd. 
progression-free survival among patients with advanced pancreatic NETs (Yao et al. 2013, 2015). Everolimus is involved in the inhibition of VEGF synthesis and secretion, together with the production of HIF $\alpha$ by the tumor cells. It specifically affects endothelial cell survival by inducing endothelial cell apoptosis and inhibiting endothelial progenitor cell proliferation and differentiation. In conclusion, the inhibition of mTOR pathway indirectly affects the new vessel formation process, resulting in dual, direct and indirect, tumor growth impairment.

Another example of non-targeted therapies with possible anti-angiogenic properties is somatostatin analogs (SSAs). Somatostatin is a peptide hormone with the ability to prevent hormone release and cell growth after binding to its receptors $\left(\right.$ sst $_{1}-$ sst $\left._{5}\right)$. Due to the short half-life of native somatostatin and the rebound hormone hypersecretion, clinically useful analogs have been developed. The best known SSAs approved by the FDA for NET treatment are octreotide (Sandostatin; Novartis) and lanreotide (Somatuline; Ipsen). Besides their antiproliferative effect on tumor cells, SSAs demonstrate strong anti-angiogenic properties in vitro by inhibiting endothelial cell proliferation and the synthesis and secretion of several angiogenic factors such as VEGF either in stromal or tumor cells (Danesi \& Del Tacca 1996, Woltering et al. 1997). Nevertheless, the translation of the in vitro anti-angiogenic properties of somatostatin and SSAs to the in vivo setting and its potential exploitation in human disease remains controversial, and little evidence exists (Walter et al. 2011).

\section{Overcoming the hurdles and shaping the future of NET treatment}

Some of the main characteristics of NETs are their high vascularization and their capacity to synthesize and secrete high levels of VEGF. Due to the limitations of chemotherapeutics, the use of anti-angiogenic molecules to try to inhibit neovessel formation to fight against tumor growth is currently explored. In short, tumor angiogenesis inhibition will engage tumor cell death via lack of oxygen and nutrient deprivation.

Angiogenesis is a complex process in which several biological mechanisms are involved: endothelial cell proliferation, vessel guidance, vessel maturation, stabilization and quiescence. During all these steps, there is an interplay between different molecular families, including growth factors, migratory cues and other signaling molecules, which is crucial to understand the process of tumor angiogenesis as a promising target to fight against cancer. It has been shown that the blockade of endothelial cells, tumor stroma cells (pericytes, fibroblast and immune cells) or extracellular matrix remodeling molecules produces tumor blood vessel reduction. Hence, due to the high number of molecules and different cell types involved in vessel formation, angiogenic processes can be inhibited at different levels (Fig. 1). Nevertheless, the canonical VEGF pathway is the most studied one and, for this reason, many inhibitors have been developed to block the action of VEGF or its receptors, VEGFRs.

Even though many angiogenesis inhibitors have been described, only some of them have been approved and used in clinics. Furthermore, the clinical benefit of anti-angiogenic drugs remains limited due to the acquisition of drug resistance by stromal cells, and they need to be improved to guarantee patient's long term response. An example of the therapy failure was observed in a preclinical study using the RIP1-Tag2 mouse model of pancreatic islet carcinogenesis. The initial efficacy of anti-angiogenic therapy in vivo was then followed by the acquisition of resistance as demonstrated by tumor revascularization, regrowth and invasiveness (Casanovas et al. 2005). Efforts for a better understanding of the mechanism underlying resistance to therapy aided to describe intrinsic (primary) and adaptive (secondary) resistance as the main modes of non-responsiveness to antitumor therapy. While intrinsic resistance refers to naturally non-responder tumors to anti-angiogenic therapies such as sunitinib and bevacizumab (Edelman \& Mao 2013), acquired or adaptive resistance stems from tumor adaptations to therapy. The latter includes the creation of alternative mechanisms that lead to additional proangiogenic signaling pathways activation (JimenezValerio \& Casanovas 2016). Current notion regarding anti-angiogenic resistance has led to the conclusion that the blocking of the classical VEGF pathway alone does not consistently alter neovascularization in tumors, and more efficient results are obtained when multiple growth factor pathways are simultaneously affected.

There is a need to identify and characterize additional molecular regulators of angiogenesis in order to develop new drugs. It has been described that, during tumor evolution, different angiogenic molecules are expressed at different levels depending on the tumor progression status. For instance, during the early stages of breast cancer, tumors require only VEGF for angiogenesis, whereas at later stages, other factors such as FGF and PDGF are needed. Therefore, a late-stage breast tumor http://jme.endocrinology-journals.org DOI: 10.1530/JME-17-0029
(C) 2017 The authors Printed in Great Britain
Published by Bioscientifica Ltd 
cell may not respond to classical anti-VEGF treatment because alternative angiogenic factors are involved in the angiogenesis process. In this context, combinatorial strategies are also required to disrupt several receptor and non-receptor kinases in association with classic clinical drugs such as anti-VEGF. In the future, new drugs targeting PDGF, FGF, EGF or semaphorin pathways will help to improve the therapeutic effect against cancer cells, vascular and other stromal cells in NETs (Fig. 1). In conclusion, in order to fight against tumor progression, normalize tumor vasculature and avoid drug resistance and tumor regrowth, there is an increasing urge to combine several vessel formation-targeted therapies. The strategy is based on the combination of therapies that target multiple components of the tumor stroma in order to inhibit tumor growth from different stages of vessel formation. Nevertheless, clinical trials combining drugs targeting two crucial pathways such as VEGF and mTOR have demonstrated undesirable side effects in terms of efficacy due to an increased toxicity, For example, a phase II study of the combination of sorafenib and bevacizumab for patients with advanced NETs resulted in a global PFS rate of 90.9\% (Castellano et al. 2013). Unfortunately, unfavorable safety results were showed in comparison to these same drugs in monotherapy, arguing that a sequential approach should be used instead. On the contrary, new preclinical and clinical data are giving evidence of antitumor efficacy of dual inhibition in the presence of moderate toxicity in other types of tumors such as metastatic renal cell carcinoma (Motzer et al. 2016). In the future, further research in the field of angiogenesis will allow the development of new combinatorial strategies where pharmacological toxicity is limited. Multi-targeting will, undoubtedly, lead to reduced resistance and improved therapeutic outcome in patients who are receiving anti-angiogenic therapy.

\section{Declaration of interest}

Oriol Casanovas declares that he has been economically compensated for his assistance to advisory boards and conferences from Novartis, Pfizer, Ipsen and Teva. Apart from this, there is no conflict of interest that could be perceived as prejudicing the impartiality of the research reported.

\section{Acknowledgements}

The authors' work is supported by research grants from EU-FP7-ERC (STROMALIGN ERC-StG-281830), MinEco Spain (SAF2016-79347-R), ISCIII Spain (PIE13/00022-5) and AGAUR-Generalitat de Catalunya (SGR2014725). Some of these include European Development Regional Funds (ERDF 'a way to achieve Europe').

\section{References}

Ahn HK, Choi JY, Kim KM, Kim H, Choi SH, Park SH, Park JO, Lim HY, Kang WK, Lee J, et al. 2013 Phase II study of pazopanib monotherapy in metastatic gastroenteropancreatic neuroendocrine tumours. British Journal of Cancer 109 1414-1419. (doi:10.1038/ bjc.2013.470)

Allen E, Walters IB \& Hanahan D 2011 Brivanib, a dual FGF/VEGF inhibitor, is active both first and second line against mouse pancreatic neuroendocrine tumors developing adaptive/evasive resistance to VEGF inhibition. Clinical Cancer Research 17 5299-5310. (doi:10.1158/1078-0432.CCR-10-2847)

Amin DN, Hida K, Bielenberg DR \& Klagsbrun M 2006 Tumor endothelial cells express epidermal growth factor receptor (EGFR) but not ErbB3 and are responsive to EGF and to EGFR kinase inhibitors. Cancer Research 66 2173-2180. (doi:10.1158/0008-5472. CAN-05-3387)

Andrae J, Gallini R \& Betsholtz C 2008 Role of platelet-derived growth factors in physiology and medicine. Genes and Development 22 1276-1312. (doi:10.1101/gad.1653708)

Baka S, Clamp AR \& Jayson GC 2006 A review of the latest clinical compounds to inhibit VEGF in pathological angiogenesis. Expert Opinion on Therapeutic Targets $10867-876$. (doi:10.1517/14728222.10.6.867)

Baker CH, Pino MS \& Fidler IJ 2006 Phosphorylated epidermal growth factor receptor on tumor-associated endothelial cells in human renal cell carcinoma is a primary target for therapy by tyrosine kinase inhibitors. Neoplasia 8 470-476. (doi:10.1593/neo.06172)

Baluk P, Hashizume H \& McDonald DM 2005 Cellular abnormalities of blood vessels as targets in cancer. Current Opinion in Genetics and Development 15 102-111. (doi:10.1016/j.gde.2004.12.005)

Banu N, Teichman J, Dunlap-Brown M, Villegas G \& Tufro A 2006 Semaphorin 3C regulates endothelial cell function by increasing integrin activity. FASEB Journal 20 2150-2152. (doi:10.1096/fj.055698fje)

Basile JR, Barac A, Zhu T, Guan KL \& Gutkind JS 2004 Class IV semaphorins promote angiogenesis by stimulating Rho-initiated pathways through plexin-B. Cancer Research 64 5212-5224. (doi:10.1158/0008-5472.CAN-04-0126)

Basile JR, Afkhami T \& Gutkind JS 2005 Semaphorin 4D/plexin-B1 induces endothelial cell migration through the activation of PYK2, Src, and the phosphatidylinositol 3-kinase-Akt pathway. Molecular and Cellular Biology 25 6889-6898. (doi:10.1128/MCB.25.16.68896898.2005)

Basile JR, Castilho RM, Williams VP \& Gutkind JS 2006 Semaphorin 4D provides a link between axon guidance processes and tumor-induced angiogenesis. PNAS 103 9017-9022. (doi:10.1073/pnas.0508825103)

Basile JR, Gavard J \& Gutkind JS 2007a Plexin-B1 utilizes RhoA and Rho kinase to promote the integrin-dependent activation of Akt and ERK and endothelial cell motility. Journal of Biological Chemistry 282 34888-34895. (doi:10.1074/jbc.M705467200)

Basile JR, Holmbeck K, Bugge TH \& Gutkind JS 2007b MT1-MMP controls tumor-induced angiogenesis through the release of semaphorin 4D. Journal of Biological Chemistry 282 6899-6905. (doi:10.1074/jbc.M609570200)

Bates D, Taylor GI, Minichiello J, Farlie P, Cichowitz A, Watson N, Klagsbrun M, Mamluk R \& Newgreen DF 2003 Neurovascular congruence results from a shared patterning mechanism that utilizes Semaphorin3A and Neuropilin-1. Developmental Biology 255 77-98. (doi:10.1016/S0012-1606(02)00045-3)

Beenken A \& Mohammadi M 2009 The FGF family: biology, pathophysiology and therapy. Nature Reviews Drug Discovery 8 235-253. (doi:10.1038/nrd2792)

Bergers G \& Benjamin LE 2003 Tumorigenesis and the angiogenic switch. Nature Reviews Cancer 3 401-410. (doi:10.1038/nrc1093) http://jme.endocrinology-journals.org

DOI: 10.1530/JME-17-0029
(C) 2017 The authors Printed in Great Britain
Published by Bioscientifica Ltd 
Bielenberg DR, Pettaway CA, Takashima S \& Klagsbrun M 2006 Neuropilins in neoplasms: expression, regulation, and function. Experimental Cell Research 312 584-593. (doi:10.1016/j. yexcr.2005.11.024)

Bourhis J, Rivera F, Mesia R, Awada A, Geoffrois L, Borel C, Humblet Y, Lopez-Pousa A, Hitt R, Vega Villegas ME, et al. 2006 Phase I/II study of cetuximab in combination with cisplatin or carboplatin and fluorouracil in patients with recurrent or metastatic squamous cell carcinoma of the head and neck. Journal of Clinical Oncology 24 2866-2872. (doi:10.1200/JCO.2005.04.3547)

Camps JL, Chang SM, Hsu TC, Freeman MR, Hong SJ, Zhau HE, von Eschenbach AC \& Chung LW 1990 Fibroblast-mediated acceleration of human epithelial tumor growth in vivo. PNAS 87 75-79. (doi:10.1073/pnas.87.1.75)

Capdevila J, Meeker A, Garcia-Carbonero R, Pietras K, Astudillo A, Casanovas O \& Scarpa A 2014 Molecular biology of neuroendocrine tumors: from pathways to biomarkers and targets. Cancer and Metastasis Reviews 33 345-351. (doi:10.1007/s10555-013-9468-y)

Casanovas O, Hicklin DJ, Bergers G \& Hanahan D 2005 Drug resistance by evasion of antiangiogenic targeting of VEGF signaling in latestage pancreatic islet tumors. Cancer Cell 8 299-309. (doi:10.1016/j. ccr.2005.09.005)

Casazza A, Fu X, Johansson I, Capparuccia L, Andersson F, Giustacchini A, Squadrito ML, Venneri MA, Mazzone M, Larsson E, et al. 2011 Systemic and targeted delivery of semaphorin 3A inhibits tumor angiogenesis and progression in mouse tumor models. Arteriosclerosis, Thrombosis, and Vascular Biology 31 741-749. (doi:10.1161/ ATVBAHA.110.211920)

Castellano D, Capdevila J, Sastre J, Alonso V, Llanos M, GarciaCarbonero R, Manzano Mozo JL, Sevilla I, Duran I \& Salazar R 2013 Sorafenib and bevacizumab combination targeted therapy in advanced neuroendocrine tumour: a phase II study of Spanish Neuroendocrine Tumour Group (GETNE0801). European Journal of Cancer 49 3780-3787. (doi:10.1016/j.ejca.2013.06.042)

Conrotto P, Valdembri D, Corso S, Serini G, Tamagnone L, Comoglio PM, Bussolino F \& Giordano S 2005 Sema4D induces angiogenesis through Met recruitment by Plexin B1. Blood 105 4321-4329. (doi:10.1182/blood-2004-07-2885)

Ch'ng ES \& Kumanogoh A 2010 Roles of Sema4D and Plexin-B1 in tumor progression. Molecular Cancer 9 251. (doi:10.1186/1476-45989-251)

Ch'ng E, Tomita Y, Zhang B, He J, Hoshida Y, Qiu Y, Morii E, Nakamichi I, Hamada K, Ueda T, et al. 2007 Prognostic significance of CD100 expression in soft tissue sarcoma. Cancer 110 164-172. (doi:10.1002/ cncr.22764)

Danesi R \& Del Tacca M 1996 The effects of the somatostatin analog octreotide on angiogenesis in vitro. Metabolism 45 49-50. (doi:10.1016/S0026-0495(96)90080-3)

Delaire S, Billard C, Tordjman R, Chedotal A, Elhabazi A, Bensussan A \& Boumsell L 2001 Biological activity of soluble CD100. II. Soluble CD100, similarly to H-SemaIII, inhibits immune cell migration. Journal of Immunology 166 4348-4354. (doi:10.4049/ jimmunol.166.7.4348)

Delbaldo C, Faivre S, Dreyer C \& Raymond E 2012 Sunitinib in advanced pancreatic neuroendocrine tumors: latest evidence and clinical potential. Therapeutic Advances in Medical Oncology 4 9-18. (doi:10.1177/1758834011428147)

Duran I, Kortmansky J, Singh D, Hirte H, Kocha W, Goss G, Le L, Oza A, Nicklee T, Ho J, et al. 2006 A phase II clinical and pharmacodynamic study of temsirolimus in advanced neuroendocrine carcinomas. British Journal of Cancer 95 1148-1154. (doi:10.1038/sj.bjc.6603419)

Edelman MJ \& Mao L 2013 Resistance to anti-angiogenic agents: a brief review of mechanisms and consequences. Translational Lung Cancer Research 2 304-307. (doi:10.3978/j.issn.22186751.2013.01.02)
Ellis LM 2004 Epidermal growth factor receptor in tumor angiogenesis. Hematology/Oncology Clinics of North America 18 1007-1021, viii. (doi:10.1016/j.hoc.2004.06.002)

Evans EE, Jonason AS Jr, Bussler H, Torno S, Veeraraghavan J, Reilly C, Doherty MA, Seils J, Winter LA, Mallow C, et al. 2015 Antibody blockade of semaphorin $4 \mathrm{D}$ promotes immune infiltration into tumor and enhances response to other immunomodulatory therapies. Cancer Immunology Research 3 689-701. (doi:10.1158/2326-6066.CIR-14-0171)

Fazzari P, Penachioni J, Gianola S, Rossi F, Eickholt BJ, Maina F, Alexopoulou L, Sottile A, Comoglio PM, Flavell RA, et al. 2007 Plexin-B1 plays a redundant role during mouse development and in tumour angiogenesis. BMC Developmental Biology 755. (doi:10.1186/1471-213X-7-55)

Fjallskog ML, Lejonklou MH, Oberg KE, Eriksson BK \& Janson ET 2003 Expression of molecular targets for tyrosine kinase receptor antagonists in malignant endocrine pancreatic tumors. Clinical Cancer Research 9 1469-1473.

Folkman J 1971 Tumor angiogenesis: therapeutic implications. New England Journal of Medicine 285 1182-1186. (doi:10.1056/ NEJM197111182852108)

Folkman J 2007 Angiogenesis: an organizing principle for drug discovery? Nature Reviews Drug Discovery 6 273-286. (doi:10.1038/ $\operatorname{nrd2115)}$

Galani E, Sgouros J, Petropoulou C, Janinis J, Aravantinos G, DionysiouAsteriou D, Skarlos D \& Gonos E 2002 Correlation of MDR-1, nm23-H1 and H Sema E gene expression with histopathological findings and clinical outcome in ovarian and breast cancer patients. Anticancer Research 22 2275-2280.

Gotink KJ \& Verheul HM 2010 Anti-angiogenic tyrosine kinase inhibitors: what is their mechanism of action? Angiogenesis 13 1-14. (doi:10.1007/s10456-009-9160-6)

Grande E, Capdevila J, Castellano D, Teule A, Duran I, Fuster J, Sevilla I, Escudero P, Sastre J, Garcia-Donas J, et al. 2015 Pazopanib in pretreated advanced neuroendocrine tumors: a phase II, open-label trial of the Spanish Task Force Group for Neuroendocrine Tumors (GETNE). Annals of Oncology 26 1987-1993. (doi:10.1093/annonc/ $\operatorname{mdv} 252)$

Grey AM, Schor AM, Rushton G, Ellis I \& Schor SL 1989 Purification of the migration stimulating factor produced by fetal and breast cancer patient fibroblasts. PNAS 86 2438-2442. (doi:10.1073/ pnas.86.7.2438)

Guttmann-Raviv N, Shraga-Heled N, Varshavsky A, Guimaraes-Sternberg C, Kessler O \& Neufeld G 2007 Semaphorin-3A and semaphorin-3F work together to repel endothelial cells and to inhibit their survival by induction of apoptosis. Journal of Biological Chemistry $\mathbf{2 8 2}$ 26294-26305. (doi:10.1074/jbc.M609711200)

Hamberg P, Verweij J \& Sleijfer S 2010 (Pre-)clinical pharmacology and activity of pazopanib, a novel multikinase angiogenesis inhibitor. Oncologist 15 539-547. (doi:10.1634/theoncologist.2009-0274)

Hanahan D 1985 Heritable formation of pancreatic beta-cell tumours in transgenic mice expressing recombinant insulin/simian virus 40 oncogenes. Nature 315 115-122. (doi:10.1038/315115a0)

Hanahan D \& Folkman J 1996 Patterns and emerging mechanisms of the angiogenic switch during tumorigenesis. Cell 86 353-364. (doi:10.1016/S0092-8674(00)80108-7)

Heldin CH \& Westermark B 1999 Mechanism of action and in vivo role of platelet-derived growth factor. Physiological Reviews 79 1283-1316.

Hellberg C, Ostman A \& Heldin CH 2010 PDGF and vessel maturation. Recent Results in Cancer Research 180 103-114. (doi:10.1007/978-3540-78281-0_7)

Herman JG \& Meadows GG 2007 Increased class 3 semaphorin expression modulates the invasive and adhesive properties of prostate cancer cells. International Journal of Oncology 30 1231-1238.

Holsinger FC, Doan DD, Jasser SA, Swan EA, Greenberg JS, Schiff BA, Bekele BN, Younes MN, Bucana CD, Fidler IJ, et al. 2003 Epidermal growth factor receptor blockade potentiates apoptosis mediated by

Published by Bioscientifica Ltd. 
Paclitaxel and leads to prolonged survival in a murine model of oral cancer. Clinical Cancer Research 9 3183-3189.

Hopfner M, Sutter AP, Gerst B, Zeitz M \& Scherubl H 2003 A novel approach in the treatment of neuroendocrine gastrointestinal tumours. Targeting the epidermal growth factor receptor by gefitinib (ZD1839). British Journal of Cancer 89 1766-1775. (doi:10.1038/sj. bjc.6601346)

Huang S, Armstrong EA, Benavente S, Chinnaiyan P \& Harari PM 2004 Dual-agent molecular targeting of the epidermal growth factor receptor (EGFR): combining anti-EGFR antibody with tyrosine kinase inhibitor. Cancer Research 64 5355-5362. (doi:10.1158/0008-5472. CAN-04-0562)

Huether A, Hopfner M, Baradari V, Schuppan D \& Scherubl H 2005 EGFR blockade by cetuximab alone or as combination therapy for growth control of hepatocellular cancer. Biochemical Pharmacology 70 1568-1578. (doi:10.1016/j.bcp.2005.09.007)

Iivanainen E, Lauttia S, Zhang N, Tvorogov D, Kulmala J, Grenman R, Salven P \& Elenius K 2009 The EGFR inhibitor gefitinib suppresses recruitment of pericytes and bone marrow-derived perivascular cells into tumor vessels. Microvascular Research 78 278-285. (doi:10.1016/j. mvr.2009.06.010)

Ivy SP, Wick JY \& Kaufman BM 2009 An overview of small-molecule inhibitors of VEGFR signaling. Nature Reviews Clinical Oncology 6 569-579. (doi:10.1038/nrclinonc.2009.130)

Jain RK 2005 Normalization of tumor vasculature: an emerging concept in antiangiogenic therapy. Science 307 58-62. (doi:10.1126/ science.1104819)

Jimenez-Valerio G \& Casanovas O 2016 Antiangiogenic resistance: novel angiogenesis axes uncovered by antiangiogenic therapies research. Current Drug Targets 17 1728-1734. (doi:10.2174/1389450117666160 301101425)

Kedar D, Baker CH, Killion JJ, Dinney CP \& Fidler IJ 2002 Blockade of the epidermal growth factor receptor signaling inhibits angiogenesis leading to regression of human renal cell carcinoma growing orthotopically in nude mice. Clinical Cancer Research 8 3592-3600.

Kessler O, Shraga-Heled N, Lange T, Gutmann-Raviv N, Sabo E, Baruch L, Machluf M \& Neufeld G 2004 Semaphorin-3F is an inhibitor of tumor angiogenesis. Cancer Research 64 1008-1015. (doi:10.1158/0008-5472.CAN-03-3090)

Klagsbrun M, Takashima S \& Mamluk R 2002 The role of neuropilin in vascular and tumor biology. Advances in Experimental Medicine and Biology 515 33-48. (doi:10.1007/978-1-4615-0119-0_3)

Klimstra DS 2016 Pathologic classification of neuroendocrine neoplasms. Hematology/Oncology Clinics of North America 30 1-19. (doi:10.1016/j. hoc.2015.08.005)

Kolodkin AL, Matthes DJ \& Goodman CS 1993 The semaphorin genes encode a family of transmembrane and secreted growth cone guidance molecules. Cell 75 1389-1399. (doi:10.1016/00928674(93)90625-Z)

Krause DS \& Van Etten RA 2005 Tyrosine kinases as targets for cancer therapy. New England Journal of Medicine 353 172-187. (doi:10.1056/ NEJMra044389)

Kulke MH 2008 Neuroendocrine tumors: is there a standard treatment? Gastrointestinal Cancer Research 2 152-153.

Kulke MH, Chan JA, Meyerhardt JA, Zhu AX, Abrams TA, Blaszkowsky LS, Regan E, Sidor C \& Fuchs CS 2010 A prospective phase II study of 2-methoxyestradiol administered in combination with bevacizumab in patients with metastatic carcinoid tumors. Cancer Chemotherapy and Pharmacology 68 293-300. (doi:10.1007/s00280010-1478-7)

Kumar R, Knick VB, Rudolph SK, Johnson JH, Crosby RM, Crouthamel MC, Hopper TM, Miller CG, Harrington LE, Onori JA, et al. 2007 Pharmacokinetic-pharmacodynamic correlation from mouse to human with pazopanib, a multikinase angiogenesis inhibitor with potent antitumor and antiangiogenic activity. Molecular Cancer Therapeutics 6 2012-2021. (doi:10.1158/1535-7163.MCT-07-0193)
Kunz PL 2015 Carcinoid and neuroendocrine tumors: building on success. Journal of Clinical Oncology 33 1855-1863. (doi:10.1200/ JCO.2014.60.2532)

Lieu C, Heymach J, Overman M, Tran H \& Kopetz S 2011 Beyond VEGF: inhibition of the fibroblast growth factor pathway and antiangiogenesis. Clinical Cancer Research 17 6130-6139. (doi:10.1158/1078-0432.CCR-11-0659)

Luo Y, Raible D \& Raper JA 1993 Collapsin: a protein in brain that induces the collapse and paralysis of neuronal growth cones. Cell $\mathbf{7 5}$ 217-227. (doi:10.1016/0092-8674(93)80064-L)

Llovet JM, Ricci S, Mazzaferro V, Hilgard P, Gane E, Blanc JF, de Oliveira AC, Santoro A, Raoul JL, Forner A, et al. 2008 Sorafenib in advanced hepatocellular carcinoma. New England Journal of Medicine 359 378-390. (doi:10.1056/NEJMoa0708857)

Maione F, Molla F, Meda C, Latini R, Zentilin L, Giacca M, Seano G, Serini G, Bussolino F \& Giraudo E 2009 Semaphorin 3A is an endogenous angiogenesis inhibitor that blocks tumor growth and normalizes tumor vasculature in transgenic mouse models. Journal of Clinical Investigation 119 3356-3372. (doi:10.1172/JCI36308)

Maione F, Capano S, Regano D, Zentilin L, Giacca M, Casanovas O, Bussolino F, Serini G \& Giraudo E 2012 Semaphorin 3A overcomes cancer hypoxia and metastatic dissemination induced by antiangiogenic treatment in mice. Journal of Clinical Investigation 122 1832-1848. (doi:10.1172/JCI58976)

Massironi S, Sciola V, Peracchi M, Ciafardini C, Spampatti MP \& Conte D 2008 Neuroendocrine tumors of the gastro-entero-pancreatic system. World Journal of Gastroenterology 14 5377-5384. (doi:10.3748/ wjg.14.5377)

Missiaglia E, Dalai I, Barbi S, Beghelli S, Falconi M, della Peruta M, Piemonti L, Capurso G, Di Florio A, delle Fave G, et al. 2009 Pancreatic endocrine tumors: expression profiling evidences a role for AKT-mTOR pathway. Journal of Clinical Oncology 28 245-255. (doi:10.1200/JCO.2008.21.5988)

Miyato H, Tsuno NH \& Kitayama J 2012 Semaphorin 3C is involved in the progression of gastric cancer. Cancer Science 103 1961-1966. (doi:10.1111/cas.12003)

Moore MJ 2005 Brief communication: a new combination in the treatment of advanced pancreatic cancer. Seminars in Oncology 32 5-6. (doi:10.1053/j.seminoncol.2005.07.017)

Morelli MP, Cascone T, Troiani T, Tuccillo C, Bianco R, Normanno N, Romano M, Veneziani BM, Fontanini G, Eckhardt SG, et al. 2006 Anti-tumor activity of the combination of cetuximab, an anti-EGFR blocking monoclonal antibody and ZD6474, an inhibitor of VEGFR and EGFR tyrosine kinases. Journal of Cellular Physiology 208 344-353. (doi:10.1002/jcp.20666)

Motzer RJ, Hutson TE, Ren M, Dutcus C \& Larkin J 2016 Independent assessment of lenvatinib plus everolimus in patients with metastatic renal cell carcinoma. Lancet Oncology 17 e4-e5. (doi:10.1016/S14702045(15)00543-4)

Moyer JD, Barbacci EG, Iwata KK, Arnold L, Boman B, Cunningham A, DiOrio C, Doty J, Morin MJ, Moyer MP, et al. 1997 Induction of apoptosis and cell cycle arrest by CP-358,774, an inhibitor of epidermal growth factor receptor tyrosine kinase. Cancer Research $\mathbf{5 7}$ $4838-4848$

O'Donnell PH \& Ratain MJ 2007 Evaluating the activity of temsirolimus in neuroendocrine cancer. British Journal of Cancer 96 177; author reply 178-179. (doi:10.1038/sj.bjc.6603514)

Oberg K \& Castellano D 2008 Current knowledge on diagnosis and staging of neuroendocrine tumors. Cancer and Metastasis Reviews 30 (Supplement 1) 3-7. (doi:10.1007/s10555-011-9292-1)

Pan G, Lv H, Ren H, Wang Y, Liu Y, Jiang H \& Wen J 2010 Elevated expression of semaphorin $5 \mathrm{~A}$ in human gastric cancer and its implication in carcinogenesis. Life Sciences 86 139-144. (doi:10.1016/j.lfs.2009.12.004)

Perrotte P, Matsumoto T, Inoue K, Kuniyasu H, Eve BY, Hicklin DJ, Radinsky R \& Dinney CP 1999 Anti-epidermal growth factor receptor

Published by Bioscientifica Ltd 
antibody C225 inhibits angiogenesis in human transitional cell carcinoma growing orthotopically in nude mice. Clinical Cancer Research 5 257-265.

Petit AM, Rak J, Hung MC, Rockwell P, Goldstein N, Fendly B \& Kerbel RS 1997 Neutralizing antibodies against epidermal growth factor and ErbB-2/neu receptor tyrosine kinases down-regulate vascular endothelial growth factor production by tumor cells in vitro and in vivo: angiogenic implications for signal transduction therapy of solid tumors. American Journal of Pathology 151 1523-1530.

Picard O, Rolland Y \& Poupon MF 1986 Fibroblast-dependent tumorigenicity of cells in nude mice: implication for implantation of metastases. Cancer Research 46 3290-3294.

Pircher A, Wellbrock J, Fiedler W, Heidegger I, Gunsilius E \& Hilbe W 2014 New antiangiogenic strategies beyond inhibition of vascular endothelial growth factor with special focus on axon guidance molecules. Oncology 86 46-52. (doi:10.1159/000356871)

Presta M, Dell'Era P, Mitola S, Moroni E, Ronca R \& Rusnati M 2005 Fibroblast growth factor/fibroblast growth factor receptor system in angiogenesis. Cytokine and Growth Factor Reviews 16 159-178. (doi:10.1016/j.cytogfr.2005.01.004)

Ranson M \& Wardell S 2004 Gefitinib, a novel, orally administered agent for the treatment of cancer. Journal of Clinical Pharmacy and Therapeutics 29 95-103. (doi:10.1111/j.1365-2710.2004.00543.x)

Raymond E, Dahan L, Raoul JL, Bang YJ, Borbath I, Lombard-Bohas C, Valle J, Metrakos P, Smith D, Vinik A, et al. 2011a Sunitinib malate for the treatment of pancreatic neuroendocrine tumors. New England Journal of Medicine 364 501-513. (doi:10.1056/NEJMoa1003825)

Raymond E, Hobday T, Castellano D, Reidy-Lagunes D, GarciaCarbonero R \& Carrato A $2011 b$ Therapy innovations: tyrosine kinase inhibitors for the treatment of pancreatic neuroendocrine tumors. Cancer and Metastasis Reviews 30 (Supplement 1) 19-26. (doi:10.1007/s10555-011-9291-2)

Ritter CA \& Arteaga CL 2003 The epidermal growth factor receptortyrosine kinase: a promising therapeutic target in solid tumors. Seminars in Oncology 30 3-11. (doi:10.1053/sonc.2003.50027)

Roodink I, Kats G, van Kempen L, Grunberg M, Maass C, Verrijp K, Raats J \& Leenders W 2008 Semaphorin 3E expression correlates inversely with Plexin D1 during tumor progression. American Journal of Pathology 173 1873-1881. (doi:10.2353/ajpath.2008.080136)

Sadanandam A, Varney ML, Kinarsky L, Ali H, Mosley RL \& Singh RK 2007 Identification of functional cell adhesion molecules with a potential role in metastasis by a combination of in vivo phage display and in silico analysis. OMICS 11 41-57. (doi:10.1089/ omi.2006.0004)

Sadanandam A, Rosenbaugh EG, Singh S, Varney M \& Singh RK 2010a Semaphorin $5 \mathrm{~A}$ promotes angiogenesis by increasing endothelial cell proliferation, migration, and decreasing apoptosis. Microvascular Research 79 1-9. (doi:10.1016/j.mvr.2009.10.005)

Sadanandam A, Varney ML, Singh S, Ashour AE, Moniaux N, Deb S, Lele SM, Batra SK \& Singh RK $2010 b$ High gene expression of semaphorin $5 \mathrm{~A}$ in pancreatic cancer is associated with tumor growth, invasion and metastasis. International Journal of Cancer 127 1373-1383. (doi:10.1002/ijc.25166)

Sadanandam A, Sidhu SS, Wullschleger S, Singh S, Varney ML, Yang CS, Ashour AE, Batra SK \& Singh RK 2012 Secreted semaphorin 5A suppressed pancreatic tumour burden but increased metastasis and endothelial cell proliferation. British Journal of Cancer 107 501-507. (doi:10.1038/bjc.2012.298)

Schwarz Q, Gu C, Fujisawa H, Sabelko K, Gertsenstein M, Nagy A, Taniguchi M, Kolodkin AL, Ginty DD, Shima DT, et al. 2004 Vascular endothelial growth factor controls neuronal migration and cooperates with Sema3A to pattern distinct compartments of the facial nerve. Genes and Development 18 2822-2834. (doi:10.1101/ gad.322904)

Serini G, Valdembri D, Zanivan S, Morterra G, Burkhardt C, Caccavari F, Zammataro L, Primo L, Tamagnone L, Logan M, et al. 2003 Class 3 semaphorins control vascular morphogenesis by inhibiting integrin function. Nature 424 391-397. (doi:10.1038/nature01784)

Shah T, Hochhauser D, Frow R, Quaglia A, Dhillon AP \& Caplin ME 2006 Epidermal growth factor receptor expression and activation in neuroendocrine tumours. Journal of Neuroendocrinology 18 355-360. (doi:10.1111/j.1365-2826.2006.01425.x)

Sini P, Wyder L, Schnell C, O'Reilly T, Littlewood A, Brandt R, Hynes NE $\&$ Wood J 2005 The antitumor and antiangiogenic activity of vascular endothelial growth factor receptor inhibition is potentiated by ErbB1 blockade. Clinical Cancer Research 11 4521-4532. (doi:10.1158/1078-0432.CCR-04-1954)

Suchting S, Bicknell R \& Eichmann A 2005 Neuronal clues to vascular guidance. Experimental Cell Research 312 668-675. (doi:10.1016/j. yexcr.2005.11.009)

Tamagnone L \& Comoglio PM 2004 To move or not to move? Semaphorin signalling in cell migration. EMBO Reports 5 356-361. (doi:10.1038/sj.embor.7400114)

Terris B, Scoazec JY, Rubbia L, Bregeaud L, Pepper MS, Ruszniewski P, Belghiti J, Flejou J \& Degott C 1998 Expression of vascular endothelial growth factor in digestive neuroendocrine tumours. Histopathology 32 133-138. (doi:10.1046/j.1365-2559.1998.00321.x)

Thaker PH, Yazici S, Nilsson MB, Yokoi K, Tsan RZ, He J, Kim SJ, Fidler IJ \& Sood AK 2005 Antivascular therapy for orthotopic human ovarian carcinoma through blockade of the vascular endothelial growth factor and epidermal growth factor receptors. Clinical Cancer Research 11 4923-4933. (doi:10.1158/1078-0432.CCR-04-2060)

Varshavsky A, Kessler O, Abramovitch S, Kigel B, Zaffryar S, Akiri G \& Neufeld G 2008 Semaphorin-3B is an angiogenesis inhibitor that is inactivated by furin-like pro-protein convertases. Cancer Research $\mathbf{6 8}$ 6922-6931. (doi:10.1158/0008-5472.CAN-07-5408)

Walter T, Hommell-Fontaine J, Gouysse G, Pourreyron C, Nejjari M, Villaume K, Causeret S, Hervieu V, Poncet G, Roche C, et al. 2011 Effects of somatostatin and octreotide on the interactions between neoplastic gastroenteropancreatic endocrine cells and endothelial cells: a comparison between in vitro and in vivo properties. Neuroendocrinology 94 200-208. (doi:10.1159/000328134)

Wang JS, Jing CQ, Shan KS, Chen YZ, Guo XB, Cao ZX, Mu LJ, Peng LP, Zhou ML \& Li LP 2015 Semaphorin 4D and hypoxia-inducible factor-1alpha overexpression is related to prognosis in colorectal carcinoma. World Journal of Gastroenterology 21 2191-2198. (doi:10.3748/wjg.v21.i7.2191)

Woltering EA, Watson JC, Alperin-Lea RC, Sharma C, Keenan E, Kurozawa D \& Barrie R 1997 Somatostatin analogs: angiogenesis inhibitors with novel mechanisms of action. Investigational New Drugs 15 77-86. (doi:10.1023/A:1005774713202)

Yao JC, Hassan M, Phan A, Dagohoy C, Leary C, Mares JE, Abdalla EK, Fleming JB, Vauthey JN, Rashid A, et al. 2008a One hundred years after 'carcinoid': epidemiology of and prognostic factors for neuroendocrine tumors in 35,825 cases in the United States. Journal of Clinical Oncology 26 3063-3072. (doi:10.1200/JCO.2007.15.4377)

Yao JC, Phan A, Hoff PM, Chen HX, Charnsangavej C, Yeung SC, Hess $\mathrm{K}, \mathrm{Ng}$ C, Abbruzzese JL \& Ajani JA 2008b Targeting vascular endothelial growth factor in advanced carcinoid tumor: a random assignment phase II study of depot octreotide with bevacizumab and pegylated interferon alpha-2b. Journal of Clinical Oncology 26 1316-1323. (doi:10.1200/JCO.2007.13.6374)

Yao JC, Phan AT, Jehl V, Shah G \& Meric-Bernstam F 2013 Everolimus in advanced pancreatic neuroendocrine tumors: the clinical experience. http://jme.endocrinology-journals.org

DOI: 10.1530/JME-17-0029
(C) 2017 The authors Printed in Great Britain
Published by Bioscientifica Ltd 
Cancer Research 73 1449-1453. (doi:10.1158/0008-5472.CAN-123923)

Yao JC, Fazio N, Singh S, Buzzoni R, Carnaghi C, Wolin E, Tomasek J, Raderer M, Lahner H, Voi M, et al. 2015 Everolimus for the treatment of advanced, non-functional neuroendocrine tumours of the lung or gastrointestinal tract (RADIANT-4): a randomised, placebo-controlled, phase 3 study. Lancet 387 968-977. (doi:10.1016/S0140-6736(15)00817-X)

Yokoi K, Thaker PH, Yazici S, Rebhun RR, Nam DH, He J, Kim SJ, Abbruzzese JL, Hamilton SR \& Fidler IJ 2005 Dual inhibition of epidermal growth factor receptor and vascular endothelial growth factor receptor phosphorylation by AEE788 reduces growth and metastasis of human colon carcinoma in an orthotopic nude mouse model. Cancer Research 65 3716-3725. (doi:10.1158/0008-5472.CAN04-3700)

Yonenaga Y, Mori A, Onodera H, Yasuda S, Oe H, Fujimoto A, Tachibana T \& Imamura M 2005 Absence of smooth muscle actin-positive pericyte coverage of tumor vessels correlates with hematogenous metastasis and prognosis of colorectal cancer patients. Oncology 69 159-166. (doi:10.1159/000087840)

Zhou Y, Gunput RA \& Pasterkamp RJ 2008 Semaphorin signaling: progress made and promises ahead. Trends in Biochemical Sciences 33 161-170. (doi:10.1016/j.tibs.2008.01.006)

Received in final form 6 April 2017

Accepted 3 May 2017

Accepted Preprint published online 3 May 2017
Published by Bioscientifica Ltd 